\title{
Serum Calcium Levels in Chronic Kidney Disease Patient Stratified By Body Mass Index
}

\author{
Anthoni, ${ }^{1}$ Rudi Supriyadi, ${ }^{2}$ Siti Nur Fatimah ${ }^{3}$ \\ ${ }^{1}$ Faculty of Medicine Universitas Padjadjaran, ${ }^{2}$ Department of Internal Medicine Faculty of \\ Medicine Universitas Padjadjaran/Dr. Hasan Sadikin General Hospital Bandung, ${ }^{3}$ Department of \\ Public Health Faculty of Medicine UniversitasPadjadjaran
}

\section{Abstract}

Background: Most of the chronic kidney disease (CKD) patients have low blood calcium levels, yet hypercalcemia has a worse outcome in CKD patients. Interestingly, CKD patients with higher body mass index (BMI) have better outcomes. This study aimed to elucidate the difference in blood calcium levels stratified by BMI categories in patients with CKD.

Methods: The study was conducted using a comparative analytical cross-sectional study design. Patients with CKD (n100), aged over 18 years old were included, Patients with the following were excluded: the history of hemodialysis, history of antioxidants, calcium and vitamin D supplement consumption, history of infection and malignancy. BMI of patients was categorized into underweight $(<18.5 \mathrm{~kg} / \mathrm{m} 2)$, normal $(8.5-22.9 \mathrm{~kg} / \mathrm{m} 2)$, and overweight or obese ( $\geq 23 \mathrm{~kg} / \mathrm{m} 2)$. Data were analyzed to compare blood calcium in different categories of BMI (Kruskal-Wallis test).

Results: The age of patients with CKD included in this study had median age of 61 years old, predominantly was men (57\%). The blood calcium level of CKD patients was on the lower border of the normal range. Median BMI was $23.48 \mathrm{~kg} / \mathrm{m}^{2}$, of which $53 \%$ was categorized as overweight or obese. There was a trend that overweight/obese patients had higher blood calcium levels than underweight and normal-weight patients, however, no statistically significant difference between the BMI category $(\mathrm{p}=0.982)$.

Conclusions: The blood calcium level in chronic kidney disease varies across the BMI category, however, no correlation with the BMI.

Keywords: Blood calcium, body mass index, chronic kidney disease

\section{Introduction}

Chronic kidney disease (CKD) is a chronic inflammatory condition of the kidney that present for more than 3 months and accompanied by structural and functional abnormalities, with implications for health. ${ }^{1,2}$ Estimated prevalence of CKD is $13.4 \%$ worldwide and $0.2 \%$ in Indonesia. ${ }^{3,4}$ Based on Global Burden of Disease 2015, kidney disease ranks $12^{\text {th }}$ as the main cause of death, ${ }^{5}$ whereas in Indonesia, CKD ranks $2^{\text {nd }}$ as the highest expense of Indonesia's Badan Penyelenggara Jaminan Sosial (BPJS). ${ }^{3}$ Chronic kidney disease is classified into five stages based on glomerular filtration rate (GFR) and/or on presence or absence of changes of kidney structure, each stage corresponds to the decreased quality of life, morbidity rate, and mortality rate. ${ }^{2,6}$ Kidney has an important role in body fluid, electrolyte regulation, and acid-base balance, hence, CKD can cause complications to heart, lungs, blood vessels, mineral and bone, muscle, nerves, and other organs. ${ }^{6,7}$ Patients with CKD stage or end-stage renal disease (ESRD) need kidney replacement therapy. ${ }^{3}$

Patients with CKD experience changes in body mineral level and bone density resulting in metabolic and clinical consequences, including the increase of fibroblast growth

Correspondence: Anthoni, Faculty of Medicine, Universitas Padjadjaran, Jalan Raya Bandung-Sumedang Km. 21, Jatinangor, Sumedang. E-mail: anthoni15002@mail.unpad.ac.id 
factor-23, parathyroid hormone (PTH), and blood phosphate; and a decrease of 1.25(OH)2D level and blood calcium level. ${ }^{8}$ The decrease of blood calcium levels in CKD patients is caused by lower calcium intake, failure of absorption, distribution, and utilization as the consequence of the decrease of vitamin D activities. ${ }^{6,9}$

Interestingly, overweight/obesity serves a one of the risk factors of CKD, and this overweight is related to hemodynamical, physiological, anatomical, and/or pathological changes of the kidney. ${ }^{3,10,11}$ However, conflicting result occurs, showing that obesity may have a higher survival rate of CKD patient, even though obesity is associated with mortality caused by the increased risk of metabolic syndrome and cardiovascular disease in a non-CKD patient, known as the obesity paradox. ${ }^{10,12-14}$

Another study result has shown that CKD patients with overweight/obese have higher blood calcium levels compared to those with underweight and normal weight. ${ }^{15}$ Blood calcium level higher than normal is correlated with a worse prognosis. ${ }^{16}$ In light with those contradicting results, this study aimed to explore blood calcium levels in CKD patients stratified based on body mass index (BMI).

\section{Methods}

This study was conducted using a comparative analytical cross-sectional study design. Secondary data from previous study "Correlation of Total Antioxidant Capacity, Vitamin D, Calcium, and Sclerostin to Body Composition of Patients with CKD Stage 3-5" had been retrieved upon approval of the Research Ethics Committee Universitas Padjadjaran, Bandung, Indonesia (794/ U6.KEP/EC/2018). Data on age, gender, blood calcium level, GFR, and BMI were collected. Blood calcium levels were categorized as low $(<8.5 \mathrm{mg} / \mathrm{dL})$ and normal $(8.5-10.5 \mathrm{mg} / \mathrm{dL})$, and BMI of patients were categorized into underweight $\left(<18.5 \mathrm{~kg} / \mathrm{m}^{2}\right)$, normal $(8.5-22.9$ $\left.\mathrm{kg} / \mathrm{m}^{2}\right)$, and overweight or obese $\left(\geq 23 \mathrm{~kg} / \mathrm{m}^{2}\right)$.

Patients with chronic kidney disease (CKD) stage 3,4 , or 5 , aged more than 18 years old were included from three hospitals in Bandung; Dr. Hasan Sadikin General Hospital Bandung, Ny. R. A. Habibie Kidney Hospital, and Dustira Hospital. Patients with a history of hemodialysis, use of vitamin D, calcium, and antioxidants (vitamin C and vitamin E) supplements, other chronic diseases, infection, and malignancy were excluded.

Table 1 Clinical Characteristics of the Chronic Kidney Disease from Bandung

\begin{tabular}{lcc}
\hline \multicolumn{1}{c}{ Characteristic } & n (\%) & Median (min-max) \\
\hline Sex & & \\
$\quad$ Male & $57(57 \%)$ & $61(24-78)$ \\
$\quad$ Female & $43(43 \%)$ & $23.48(10.54-37.99)$ \\
Age $($ years $)$ & & $17.24(10.5-18.21)$ \\
BMI $\left(\mathrm{kg} / \mathrm{m}^{2}\right)$ & & $21.45(18.72-22.94)$ \\
Underweight & $7(7 \%)$ & $26.26(23.01-37.99)$ \\
Normal & $40(40 \%)$ & \\
Overweight/obese & $53(53 \%)$ & \\
\hline
\end{tabular}

Note: BMI: body mass index; categorized into underweight $\left(<18.5 \mathrm{~kg} / \mathrm{m}^{2}\right)$, normal $\left(8.5-22.9 \mathrm{~kg} / \mathrm{m}^{2}\right)$, and overweight or obese $\left(\geq 23 \mathrm{~kg} / \mathrm{m}^{2}\right)$.

Table 2 Blood Calcium Level among Chronic Kidney Disease

\begin{tabular}{lcc}
\hline \multicolumn{1}{c}{ Calcium level } & n (\%) & Median (min-max) \\
\hline Calcium level $(\mathrm{mg} / \mathrm{dL})$ & $8.6(4.2-10.2)$ \\
Low & $39(39 \%)$ & $7.9(4.2-8.4)$ \\
Normal & $61(61 \%)$ & $8.9(8.5-10.2)$ \\
\hline Note: Calcium level was categorized as low $(<8.5 \mathrm{mg} / \mathrm{dL})$ and normal $(8.5-10.5 \mathrm{mg} / \mathrm{dL})$ &
\end{tabular}


Table 3 Glomerular Filtration Rate among Chronic Kidney Disease Based on Body Mass Index

\begin{tabular}{|c|c|c|c|c|}
\hline \multirow{2}{*}{ Characteristics } & \multicolumn{3}{|c|}{ BMI } & \multirow{2}{*}{ p-value } \\
\hline & $\begin{array}{c}\text { Underweight } \\
(\mathrm{n}=7)\end{array}$ & $\begin{array}{l}\text { Normal } \\
(\mathrm{n}=40)\end{array}$ & $\begin{array}{c}\text { Overweight/obese } \\
(n=53)\end{array}$ & \\
\hline \multicolumn{5}{|l|}{ Gender } \\
\hline Male(n=57) & $2(28.57 \%)$ & 22 (55\%) & 33 (62.26\%) & $0.226^{*}$ \\
\hline Female(n=43) & $5(71.43 \%)$ & $18(45 \%)$ & $20(37.74 \%)$ & \\
\hline \multicolumn{5}{|l|}{ Age (years) } \\
\hline$\leq 50$ years $(\mathrm{n}=27)$ & $3(42.86 \%)$ & $9(22.50 \%)$ & $15(28.30 \%)$ & $0.509^{*}$ \\
\hline$>50$ years $(n=73)$ & $4(57.14 \%)$ & $31(77.50 \%)$ & $38(71.70 \%)$ & \\
\hline GFR (mL/min $/ 1,73 \mathrm{~m} 2)$ & $10.54(6.64-42.85)$ & $14.36(2.38-58.64)$ & $18.81(1.85-58.01)$ & $0.458^{* *}$ \\
\hline CKD Stage 3(30-59) & $1(14.29 \%)$ & $9(22.5 \%)$ & $11(20.75 \%)$ & $0.083^{*}$ \\
\hline CKD Stage 4 (15-29) & $0(0 \%)$ & $11(27.5 \%)$ & $23(43.40 \%)$ & \\
\hline CKD Stage $5(<15)$ & $6(85.71 \%)$ & $20(50 \%)$ & $19(35.85 \%)$ & \\
\hline
\end{tabular}

Note: BMI: body mass index; categorized into underweight $\left(<18.5 \mathrm{~kg} / \mathrm{m}^{2}\right)$, normal $\left(8.5-22.9 \mathrm{~kg} / \mathrm{m}^{2}\right)$, and overweight or obese ( $\geq 23 \mathrm{~kg} / \mathrm{m} 2$ ). ${ }^{*}$ Chi-square test; ${ }^{* *}$ Kruskal-Wallis test; GFR: glomerular filtration rate; CKD: chronic kidney disease

Comparative analysis between blood calcium level among different BMI was conducted using Kruskal-Wallis test and posthoc Mann-Whitney test. A post-hoc test was conducted to elaborate the difference between BMI groups. A significant result was reached when $p<0.05 \quad($ IBM $\AA$ SPSS $₫$ Statistics 22 program).

\section{Results}

In a total sample of a previous study $(\mathrm{n}=100)$, there were $57 \%$ male CDK patients as shown in Table 1 . The median age was 61 years old (range 24-78 years old). Overweight/obese was observed in $53 \%$ of the cases, and $7 \%$ was underweight.

The characteristic of blood calcium levels in subjects is shown in Table 2. Median of blood calcium level was $8.6 \mathrm{mg} / \mathrm{dL}, 61 \%$ subject had normal calcium level.
The CKD patients were categorized into body mass index (BMI) as followed underweight $\left(\mathrm{BMI}<18.5 \mathrm{~kg} / \mathrm{m}^{2}\right)$, normal (BMI $=18.5-22.9 \mathrm{~kg} /$ $\mathrm{m}^{2}$ ), and overweight/obese (BMI $\geq 23 \mathrm{~kg} / \mathrm{m}^{2}$ ) (Table 3). There was no difference in age and gender group. Interestingly, the GFR tended to increase in overweight/obese although the increase was not statistically significant ( $p$ 0.509) (Table 3).

Blood calcium levels based on BMI category was shown in Table 4. Overall, blood calcium levels in CKD patients were at the lower limit of the normal value of blood calcium. Statistical test results revealed no difference in blood calcium levels in each BMI category.

\section{Discussion}

Chronic kidney disease (CKD) affects males predominantly as shown in our study, consisting of a male (57\%) and female (43\%).

Table 4 Blood Calcium Level Based on Body Mass Index

\begin{tabular}{|c|c|c|c|c|}
\hline \multirow{2}{*}{ BMI Category } & \multirow{2}{*}{$\mathbf{n}$} & \multirow{2}{*}{$\%$} & Blood calcium level & \multirow{2}{*}{ p-value } \\
\hline & & & Median (min-max) & \\
\hline Underweight & 7 & $7 \%$ & $8.6(7.1-9.5)$ & $0.982^{*}$ \\
\hline Normal & 40 & $40 \%$ & $8.6(5.6-10.2)$ & \\
\hline Overweight/obese & 53 & $53 \%$ & $8.8(4.2-10.0)$ & \\
\hline
\end{tabular}

Note: *Kruskal-Wallis test; BMI: body mass index 
These findings are consistent with other studies in Canada and Japan. ${ }^{15,16}$ These studies have also resulted that most of the patients are over 50 years old, confirming that CKD is more frequent to be found in older age, as the glomerular filtration rate (GFR) decreases. ${ }^{2}$

Patients with CKD have decreased kidney function, marked by the declining of GFR. ${ }^{1}$ Decreasing GFR causes phosphate retention which will increase the synthesis of FGF$23 .{ }^{17}$ Increased levels of FGF-23 to reduce the function of the enzyme 1- $\alpha$ hydroxylase, therefore, the synthesis of $1.25(\mathrm{OH}) 2 \mathrm{D}$ will decrease. ${ }^{9,17}$ Decreased levels of $1.25(\mathrm{OH}) 2 \mathrm{D}$ results in reduced calcium absorption in the intestine, increased calcium excretion, and decreased calcium resorption from bone, and thus, blood calcium levels will decrease. ${ }^{9,17}$ This explains the condition of our CKD patients that calcium level, in general, is at the lower limit of the normal value of blood calcium levels.

The distribution of blood calcium levels in each BMI group showed that there is a tendency for higher blood calcium levels in the overweight/obese group (Table 4). This finding confirms that blood calcium levels are significantly higher in obese groups. ${ }^{18}$ The abnormal calcium metabolism occurs in the overweight/obese group due to reduced $25(\mathrm{OH})$ D levels. ${ }^{18,19}$ This situation results in reduced calcium absorption in the intestine, reduced bone mineralization process, and increased calcium excretion which causes increased parathyroid hormone (PTH), therefore, the blood calcium levels will increase. Furthermore, overweight/obese groups tend to have a higher fat mass, and this will indirectly increase the activity of proinflammatory cytokines so that osteoclast activity and bone resorption increase. ${ }^{9,18}$ This increase causes blood calcium levels in the overweight/obese group to be higher than those with underweight and normal BMI.

The overweight/obese group has higher GFR than those with underweight and normal BMI (Table 2). The Glomerular filtration rate is higher, blood phosphorus and FGF-23 levels are decreased, so that $1.25(\mathrm{OH}) 2 \mathrm{D}$ level increase. ${ }^{16}$ Increased levels of $1.25(\mathrm{OH}) 2 \mathrm{D}$ will cause blood calcium levels to increase, ${ }^{16}$ resulting in higher calcium levels in the overweight/obese group of CKD patients.

The limitation of this study was that this study is not considering other factors that affect blood calcium levels, including the amount of calcium intake, vitamin D levels, PTH levels, FGF-23 levels, and phosphate levels. ${ }^{17}$
To conclude, our study failed to show the difference in blood calcium levels in chronic kidney disease in various body mass indexes. Further research that considers the factors that influence blood calcium levels needs to be explored to determine the relationship between calcium levels in patients with chronic kidney disease with various body mass index groups.

\section{References}

1. Kidney Disease: Improving Global Outcomes (KDIGO) CKD-MBD Update Work Group. KDIGO 2017 clinical Practice guideline update for the diagnosis, evaluation, prevention, and treatment of chronic kidney disease-mineral and bone disorder (CKD-MBD). Kidney Int Suppl. 2017;7(1):1-59.

2. Glassock RJ, Rule AD. Aging and the kidneys: anatomy, physiology, and consequences for defining chronic kidney disease. Nephron. 2016;134(1):25-9.

3. Pusat Data dan Informasi Kementerian Kesehatan RI. Situasi penyakit ginjal kronis. Jakarta: Data dan Informasi Kementerian Kesehatan RI; 2017.

4. Kementerian Kesehatan RI. Risetkesehatan dasar. Jakarta: Badan Penelitian dan Pengembangan Kesehatan Departemen Kesehatan Republik Indonesia; 2013.

5. Neuen BL, Chadban SJ, Demaio AR,Johnson DW, Perkovic V. Chronic kidney disease and the global NCDs agenda. BMJ Glob Health. 2017;2(2):e000380.

6. Dhondup T, Qian Q. Electrolyte and acidbase disorders in chronic kidney disease and end-stage kidney failure. Blood Purif. 2017;43(1-3):179-88.

7. Zoccali C, Vanholder R, Massy ZA, Ortiz A, Sarafidis P, Dekker FW, et al. The systemic nature of CKD. Nat Rev Nephrol. 2017;13(6):344-58.

8. Hill Gallant KM, Spiegel DM. Calcium balance in chronic kidney disease. Curr Osteoporos Rep. 2017;15(3):214-21.

9. Shanahan CM, Crouthamel MH, Kapustin A, Giachelli CM. Arterial calcification in chronic kidney disease: key roles for calcium and phosphate. Circ Res. 2011;109(6):697-711.

10. Kalantar-Zadeh K, Streja E, Kovesdy CP, Oreopoulos A, Noori N, Jing J, et al. The obesity paradox and mortality associated with surrogates of body size and muscle mass in patients receiving hemodialysis. Mayo Clin Proc. 2010;85(11):991-1001. 
11. Kopple JD, Feroze U. The effect of obesity on chronic kidney disease. J Ren Nutr. 2011;21(1):66-71.

12. Mafra D, Guebre-Egziabher F, Fouque D. Body mass index, muscle and fat in chronic kidney disease: questions about survival. Nephrol Dial Transplant. 2008;23(8):2461-6.

13. Bonanni A, Mannucci I, Verzola D, Sofia A, Saffioti S, Gianetta E, et al. Protein-energy wasting and mortality in chronic kidney disease. Int J Environ Res Public Health. 2011;8(5):1631-54.

14. Rahimlu M, Shab-Bidar S, Djafarian K. Body mass index and all-cause mortality in chronic kidney disease: a dose-response meta-analysis of observational studies. J Ren Nutr. 2017;27(4):225-32.

15. Garland JS, Holden RM, Hopman WM, Gill SS, Nolan RL, Morton AR. Body mass index, coronary artery calcification, and kidney function decline in stage 3 to 5 chronic kidney disease patients. J Ren Nutr. 2013;23(1):4-11.

16. Inaguma D, Koide $S$, Takahashi $K$, Hayashi H, Hasegawa M, Yuzawa Y. Relationship between serum calcium level at dialysis initiation and subsequent prognosis. Ren Replace Ther. 2017;3:2.

17. Blaine J, Chonchol M, Levi M. Renal control of calcium, phosphate, and magnesium homeostasis. Clin J Am Soc Nephrol. 2015;10(7):1257-72.

18. Dalfardi O, Jahandideh D, Omrani GH. The correlation of serum calcium level and obesity; is there any explanation?. GMJ. 2013;2(1):26-31.

19. Rontoyanni VG, Avila JC, Kaul S, Wong R, Veeranki SP. Association between obesity and serum $25(\mathrm{OH})$ D concentrations in older Mexican adults. Nutrients. 2017;9(2):E97. 